\title{
HIV-1 Persistence in Children during Suppressive ART
}

\author{
Mary Grace Katusiime ${ }^{1, *}$, Gert U. Van Zyl ${ }^{2}$, Mark F. Cotton ${ }^{3}$ and Mary F. Kearney ${ }^{1}$ \\ 1 HIV Dynamics and Replication Program, CCR, National Cancer Institute, Frederick, MD 21702, USA; \\ kearneym@mail.nih.gov \\ 2 Division of Medical Virology, Stellenbosch University and National Health Laboratory Service Tygerberg, \\ Cape Town 8000, South Africa; guvz@sun.ac.za \\ 3 Department of Pediatrics and Child Health, Tygerberg Children's Hospital and Family Center for Research \\ with Ubuntu, Stellenbosch University, Cape Town 7505, South Africa; MCOT@sun.ac.za \\ * Correspondence: marygrace.katusiime@nih.gov
}

check for updates

Citation: Katusiime, M.G.; Van Zyl, G.U.; Cotton, M.F.; Kearney, M.F. HIV-1 Persistence in Children during Suppressive ART. Viruses 2021, 13, 1134. https://doi.org/10.3390/ v13061134

Academic Editor: Susana Tereno Valente

Received: 27 April 2021

Accepted: 8 June 2021

Published: 12 June 2021

Publisher's Note: MDPI stays neutral with regard to jurisdictional claims in published maps and institutional affiliations.

Copyright: (c) 2021 by the authors. Licensee MDPI, Basel, Switzerland. This article is an open access article distributed under the terms and conditions of the Creative Commons Attribution (CC BY) license (https:/ / creativecommons.org/licenses/by/ $4.0 /)$.

\begin{abstract}
There is a growing number of perinatally HIV-1-infected children worldwide who must maintain life-long ART. In early life, HIV-1 infection is established in an immunologically inexperienced environment in which maternal ART and immune dynamics during pregnancy play a role in reservoir establishment. Children that initiated early antiretroviral therapy (ART) and maintained long-term suppression of viremia have smaller and less diverse HIV reservoirs than adults, although their proviral landscape during ART is reported to be similar to that of adults. The ability of these early infected cells to persist long-term through clonal expansion poses a major barrier to finding a cure. Furthermore, the effects of life-long HIV persistence and ART are yet to be understood, but growing evidence suggests that these individuals are at an increased risk for developing non-AIDS-related comorbidities, which underscores the need for an HIV cure.
\end{abstract}

Keywords: HIV-1 persistence; perinatal HIV-1; HIV-1 reservoirs; children; long-term ART

\section{Introduction}

A total of 1.8 million children aged 0-14 years were living with HIV as of 2019 [1]. Of these, only $53 \%$ had access to antiretroviral therapy (ART). Furthermore, $15 \%$ of pregnant women are not on ART to prevent transmission to their unborn child. Vertical HIV transmission can occur in utero, intrapartum, or postnatally via breastfeeding. In rare cases, horizontal transmission also occurs through surrogate breastfeeding, premastication of food, and healthcare-associated transmissions [2-5]. Despite this, maternal viral load suppression by ART has been instrumental in the $52 \%$ decline in vertical transmission since 2010 [1]. Nonetheless, there are still 150,000 new HIV infections in children aged 0-14 years every year, far above the WHO target of zero new infections among infants by $2020[1,6]$. Meeting these targets may be even more challenging given the impact of the COVID-19 pandemic on access to HIV testing and ART, particularly in the developing world where $90 \%$ of vertical transmission occurs [7].

All 1.8 million children infected with HIV worldwide must maintain life-long ART, as there is no cure for HIV. Adherence to ART is a growing challenge in pediatric HIV care and widely influenced by a host of socio-economic and psychological factors [8,9]. Furthermore, cumulative drug toxicities and non-AIDS-related morbidities in those living with HIV and treated since birth are largely unknown. In older people living with HIV, an increased risk of developing ART-related morbidities such as diabetes, hypertension, and cardiovascular disease, among others, has been observed [10-14]. These ART-related morbidities may occur in individuals born with HIV as they progress in age, along with other unknown complications related to life-long infection and treatment.

The changes to the WHO treatment guidelines to accommodate all children living with HIV regardless of CD4 threshold, coupled with the increase in life expectancy from effective ART, resulted in national healthcare budgets having to cater to lifelong ART [15]. 
The high cost of treating over 1.8 million individuals (and counting) is not economically sustainable, particularly in the developing world where most of the disease burden exists. For these reasons, a cure is warranted.

During HIV-1 replication, viral RNA is reverse-transcribed to cDNA before integration into the host cell genome. In most cells, HIV infection leads to active replication, resulting in the release of new virions and the destruction of the infected cell. However, in a subset, replication-competent proviruses can remain dormant within the host cell's genome, enabling HIV to persist in this form for the lifespan of the infected cell $[16,17]$. These cells remain hidden from the effects of the immune response, are unaffected by antiretroviral drugs (which target various stages of viral replication), and can reactivate to produce new cycles of replication when therapy is interrupted. Such cells are referred to as latent reservoirs and are the major barrier to cure in ART-suppressed individuals [18]. This review aims to provide an overview of HIV-1 reservoir establishment, persistence, and long-term effects in ART-suppressed children.

\section{Reservoir Establishment in Early Life}

In the absence of ART, 50\% of children born with HIV die by the age of two years. In contrast, people who acquire HIV as adults typically survive three or more years without treatment. This difference provides evidence that the environment in which HIV infection is established in children and adults is clinically relevant $[19,20]$. In children, HIV is introduced into a largely immunologically inexperienced environment [21]. The immune system in early life supports decreased cytokine production, leading to a hypoinflammatory innate immune response [22]. Additionally, infant antibody responses are generally delayed at the onset, have a lower peak, persist for shorter periods, and have less affinity maturation and heterogeneity $[23,24]$. Furthermore, the majority of CD4+ T cells in infants are naïve and quiescent with CD4+CCR5+ expression on cell surfaces, not reaching adult levels until after 5 years of age $[25,26]$. The absolute number and percentage of CD4+ T cells in healthy children is higher than in adults and gradually declines to reach adult levels by 6 years of age (median of $54 \%$ at birth declines to $37 \%$ by $6-12$ years) $[27,28]$. Thymopoiesis is more active in early life, and thymic involution begins after puberty. In long-term-treated children living with HIV, thymic volume and activity appears to be retained and comparable to peers without HIV [29,30]. As a result, children on ART appear to have better immune reconstitution than infected adults due to the role of thymic output in repopulating naïve cells [31].

Little is known about the exact cell subsets infected by HIV during early life. Current assays that quantify HIV reservoirs measure one or more of the following: (i) infected cells-the total number of cells harboring HIV-1 DNA, (ii) inducible reservoirs-cells that produce detectable viral nucleic acid or particles on stimulation (but may not replicate), and (iii) replication-competent reservoirs-cells that produce viruses upon stimulation and then complete successive replication cycles ex vivo [32]. In adults, in vivo studies with a few participants on long-term ART have shown that although HIV primarily infects long-lived memory $\mathrm{T}$ cell subsets (i.e., central memory and stem memory), naïve cells may be an equal or greater contributor to the inducible, replication-competent reservoir [33-36]. In children, although the majority of T cells are naïve and early ART results in a limited number of detectable infected cells, the transitional memory compartment appeared to harbor a larger proportion of HIV-1 DNA than the central memory T cell compartment in a small study cohort [37]. The relative distribution of infected, inducible, and replication-competent HIV in various cell subsets remains to be shown in early-treated children, probably due to the small blood volumes and the rapid decay of infected cells in the population [38].

Studies have shown an association between viral load and biomarkers of reservoir size, indicating that reservoir seeding occurs during uncontrolled viral replication [39,40]. In the pre-ART era, there was an association between maternal viral load at delivery and neonatal pre-ART viral load, where infants had viral loads as high as $10^{6}$ HIV RNA copies/mL of plasma-comparable to levels in untreated adults [41-43]. With widespread 
access to ART, treatment that crosses the placenta may contribute to lowering pre-ART viral loads in children who become infected, to a median of $10^{4} \mathrm{HIV}$ RNA copies $/ \mathrm{mL}$ of plasma, potentially limiting the establishment of long-lived reservoirs [41-43]. Similar to adults, vertical transmissions occur over a selective genetic bottleneck, with infection most often established by a single variant [44-46]. Recent studies comparing HIV V3 envelope sequences from mother-infant transmitting pairs found that transmitted founder variants in infants are resistant to neutralization by maternal broadly neutralizing antibodies (bNabs) compared with non-transmitted variants in the mother, indicating that maternal bNabs can select for resistant variants that establish infection in the child [47-49]. Maternal immune dynamics during pregnancy, the variant(s) transmitted, maternal ART, the timing of infant ART initiation, and the unique immune environment in early life all contribute to the reservoir that is established in children with perinatally acquired HIV (Figure 1) [50].

\section{Reservoirs in Early-Treated, Long-Term Suppressed Children}

The high mortality reported among children who are born with HIV and initiate ART only when symptomatic suggests that earlier therapy is required to prevent disease progression [19,51]. To this end, in the Children with HIV Early antiRetroviral therapy (CHER) randomized trial conducted in South Africa determined that initiating ART within 12 weeks of birth, when the immune system was most immature, resulted in long-term benefits including slower disease progression and limited reservoir size [52,53].

\subsection{HIV-1 Cell-Associated DNA: A Biomarker of the Reservoir in Long-Term-Treated Children}

Quantitative PCR (qPCR) measurements of reservoir biomarkers, particularly total HIV-1 DNA (proviral load), are commonly used to estimate levels of HIV persistence during ART suppression [54-57]. Cohort studies of adults showed that early ART limits reservoir seeding particularly in long-lived CD4+ T cell subsets [58]. Likewise, several cross-sectional studies have compared proviral loads during long-term ART in early-treated vs. later-treated children. Ananworanich et al. found that after 6 years on ART, children who initiated within 6 months of birth had low proviral loads (median total HIV DNA 132 copies $/ 10^{6} \mathrm{CD} 4+\mathrm{T}$ cells; range 11-1804) [50]. A similar study found that children who initiated ART within 3 months of age had six-fold lower proviral loads than those who initiated after 3 months but within a year of life [59]. Luzuriaga et al. compared children who initiated ART within the first year of life with those who initiated after 4 years and found significantly higher proviral loads, recoverable replication competent virus, T cell activation, and slower proviral decay in the latter [37]. A study of 20 children from the CHER cohort who had viremia well-suppressed on ART for 7-8 years also found significantly lower DNA and RNA loads in those who initiated treatment within two months of birth compared with those who initiated later [53]. These findings are mirrored by others [60-67] and highlight the role of early ART in limiting the size of the HIV reservoir. This finding is well-illustrated by a recent study in children showing a positive correlation between HIV RNA area under the viral load curve in the first year of life and HIV DNA levels at one year of age [68]. Two other studies in children reported that time to first viral load suppression was strongly and positively associated with infectious provirus levels over the first two years of life [62,69].

\subsection{Measuring Infectious Virus in Long-Term Treated Children}

qPCR approaches have the benefit of being highly sensitive, high-throughput, relatively inexpensive, and requiring low sample volumes. However, the majority of proviral HIV is defective and total HIV-1 DNA assays do not distinguish between genetically defective or intact proviruses due to the high background level of defective proviruses when on ART [70]. HIV DNA qPCR assays overestimate the true size of the reservoir by more than 300-fold [70] and have high variance and bias due to the different genes and gene regions being targeted [32]. The quantitative viral outgrowth assay (qVOA) was once the gold standard for measuring the replication-competent HIV reservoir [71,72] but is now being 
replaced or used in conjunction with the Intact Proviral Detection Assay (IPDA) (more details on IPDA are provided below) [73]. qVOA involves the mitogenic reactivation of resting CD4+ T cells by limiting dilution in the presence of feeder cells to enable subsequent rounds of infection $[32,71,74]$. Maximum likelihood statistics are then used to estimate the amount of reactivated virus as infectious units per million (IUPM) [72]. There are some limitations with qVOA: it is expensive, time consuming, and requires large blood volumes, and is thus not ideal for use in pediatric cohorts. Furthermore, qVOA underestimates the reservoir size by 25-fold in adults treated during acute infection and 27-fold in those treated during chronic infection because not all genetically intact proviruses are sufficiently reactivated in vitro and may require multiple rounds of stimulation [75,76]. In a study of 14 children treated at the median age of 2 months, infectious virus was detectable by qVOA in $60 \%$ of the children after 1.8 years on ART [69]. However, when children treated around the same age were tested for infectious virus at 11.1 years on ART, none was detected, showing that HIV-1 reservoirs in early-treated children declined to levels that were undetectable by qVOA during long-term ART [77]. Further illustrating this same finding is a more recent study that compared the inducibility of viral reservoirs between perinatal and adult infection and found fewer replication-competent proviruses persisting in children on long-term ART [78]. Because the blood draws in the children were smaller, resulting in fewer cells available for these assays than in adults, comparisons between the two groups were normalized for cellular input.

\subsection{Post-ART Control of Viral Replication}

The case of the "Mississippi baby", who initiated ART within $30 \mathrm{~h}$ of life and showed no evidence of HIV replication for a period of 27 months without treatment, indicates a very low reservoir and supports the idea that early-treated infants may be ideal candidates for curative interventions [79-81]. Other recent cases of children who, following very early ART, had delayed viral rebound with no detectable virus in peripheral blood despite no evidence of immune-mediated control further highlight the role of early ART in limiting reservoir establishment [80-82]. There is evidence to suggest that, in some children, early ART can lead to post-treatment control of viral replication. For instance, post-treatment control was reported for a South African child from the CHER cohort who was diagnosed with HIV at 32 days of age and initiated time-limited ART at 8.5 weeks of age for the next 40 weeks [83]. ART was then interrupted, as per the trial, and the child remained aviremic for 9 years [83]. Another French child maintained treatment control for more than 11 years after treatment interruption. The child was diagnosed at 4 weeks of age and started ART at 3 months of age until between 5.8 and 6.8 years of age when the family discontinued treatment [82]. The immune-mediated mechanisms by which post-treatment viral control is achieved in such cases are yet to be understood. Whereas adults who started ART during Fiebig stage I had rapid viral rebound [84], up to $15 \%$ of adults from the VISCONTI cohort and the SPARTAC study, who initiated ART at a median of 10 weeks after diagnosis of primary HIV infection in VISCONTI, and 12 weeks after seroconversion in SPARTAC, were able to maintain viral load control after treatment cessation [82,85]. This suggests that whereas early infection limits the reservoir size and prevents immune exhaustion, a period of viral replication is required for an immune response to develop, which may contribute to post-treatment control [86].

\subsection{Genetic Diversity during Long-Term ART}

The genetic diversity of viral populations within infected children and adults is initially low (mean intra-patient genetic variation of $0.96 \%$ in HIV-1 gag gene) due to the genetic bottleneck that establishes infection by one or a few variants [37,80,87-92]. However, these populations quickly diversify because of the rapid uncontrolled replication involving error-prone reverse transcriptase and viral escape from immune pressure [91]. To assess the effects of early ART on genetic evolution in the reservoir, a longitudinal study of 12 children who started ART within 2 months of age found limited evolution in env, gag, 
and pol sequences after about 5.5 years on suppressive ART [90]. A similar study from the CHER cohort, comparing gag-pol sequences from pre-ART to 7-8 years on ART, utilized three phylogenetic and statistical tests to assess changes in viral population diversity and divergence between pre-ART and 7-8 years on ART. There was no evidence of viral evolution in eight fully suppressed children, whereas in the two partially suppressed children, all three tests showed significant evidence of viral evolution [61]. Moreover, the same study found a significant positive association between HIV-1 proviral loads after 7-8 years on ART and proviral diversity (calculated as average pairwise distance), suggesting that the higher the proviral load, the more diverse the viral population [61]. Similar findings were observed in adults where comparisons of sub-genomic sequences from plasma before, during, and after ART interruption showed no significant difference between proviruses prior to ART and rebounding plasma virus after ART interruption, suggesting that ART halts the cycle of ongoing replication that may lead to genetic diversification $[93,94]$.

\subsection{Reservoir Decay Kinetics and the Proviral Landscape during Long-Term ART}

The decay of proviral DNA after initiation of ART shapes the proviral landscape in long-term ART. In children who initiate ART early, HIV-1 DNA decays rapidly, likely due to the death of productively infected cells, loss of unintegrated virus, and concurrent blocking of newly infected cells $[37,95]$. Veldsman et al. recently showed that HIV-1 DNA levels (measured by qPCR) in 3/11 children who initiated ART within 8 days of birth reached undetectable levels between 6 days to 3 months on ART, while levels in the others continued to decline for a mean half-life of 64.8 days over the first 12 months [38]. Other studies in children who initiated ART between 0.6 and 3 months of age report an HIV DNA half-life of 53-107 days [68,96]. Similar to children, longitudinal qPCR measurements of proviral DNA in adults after ART initiation reveal that the steepest decay in HIV DNA occurs in the first year of ART [58,97-100]. However, longitudinal measurements of the inducible reservoir taken by qVOA reveal a slower half-life of 3.6 years [101,102]. More recently, the novel IPDA assay was used to study proviral decay in adults $[73,103,104]$. IPDA uses droplet digital PCR to target two conserved regions in the viral genome, enabling the simultaneous quantification and discernment of intact and defective genomes [73]. These studies reported differential decay between intact and defective genomes, where intact genomes appeared to decay more rapidly in the first 7 years on ART with a half-life of 4.0 years, similar to decay measurements taken by qVOA [73,102-104]. In children treated within 2 weeks of birth, IPDA measurements recorded at 2 years on ART suggested that intact proviruses decayed significantly faster than defective genomes during the first 24 weeks on ART [105].

Although it has long been known that most proviral HIV DNA that persists on long-term ART is defective, a recent study in adults utilizing near full-length proviral sequencing showed that these defects accumulate within weeks of infection [75]. In adults initiating ART during chronic infection, $98 \%$ of proviral DNA was defective while $92 \%$ was defective in those treated during the acute infection phase [75]. Of these defective genomes, $9-50 \%$ contained guanine-to-adenine ( $\mathrm{G}$ to $\mathrm{A}$ ) hypermutations caused by cytidine deaminases APOBEC3G and APOBEC3F, which act as HIV restriction factors $[70,73,106]$. Large internal deletions account for $45-68 \%$ of defects due to template switching during reverse transcription. Other defects include frameshifts and nonsense mutations introduced during reverse transcription [70,73,106-109]. However, a larger follow-up study involving 400 diverse adult participants suggested that intact proviruses by IPDA are four-fold higher than previously reported [110]. In early-treated, long-term-suppressed children, proviral structures were reported to be similar to adults assayed by near-full-length proviral sequencing. The largest proportion again has internal deletions and/or hypermutation and only up to $1 \%$ are genetically intact $[77,111]$.

\section{Clonal Expansion Maintains the Reservoir in Treated Children}

In early-treated, long-term, virally suppressed children, identical sub-genomic HIV proviral sequences were detected in PBMCs and sputum and increased in proportion 
over time [87]. Similarly, in adults, single-cell genome sequencing revealed identical viral sequences in resting CD4+ T cells that persist in various anatomical sites and rebound after treatment interruption [94,112-115]. An assay targeting the $3^{\prime}$ end of HIV and the adjacent human genome found that these identical HIV sequences also had identical sites of integration in the host, thus demonstrating the proliferation of HIV-infected cells [116]. Advances in technology have since enabled targeted, high-throughput amplification and sequencing of proviral sites of integration and revealed that latently infected cells can have identical integration sites [116-120]. Furthermore, even though most proviral DNA is defective, expanded cell clones can harbor intact proviruses that produce infectious virions and lead to non-suppressible viremia in ART adherent individuals [76,118,121-123]. In fact, during suppressive ART, at least $40-80 \%$ of infected cells are in expanded clones, implicating clonal expansion as the major mechanism maintaining the reservoir during ART [118,120,124-126].

In perinatally infected children in the CHER cohort, HIV-infected cell clones were detectable before ART initiation and remained detectable up to 9 years on suppressive treatment. In another study, a child who initiated treatment within the first week of life had a potential clone detected 7 hours after birth, suggesting that early ART alone does not interfere with the proliferation of infected cells [105,127]. In adults, clones expand to detectable levels by 4 weeks post-infection (Fiebig stage V) [128]. Based on these data, mathematical models predict that $75-95 \%$ of cells comprising the HIV reservoir are the result of cellular proliferation [128,129].

T cell proliferation can be driven by homeostatic stimuli, such as IL-5 and IL-7, that induce cell division without reactivation of resting cells $[36,76]$. Rarely, the site of proviral integration in the host genome, particularly sites in genes responsible for cell growth and survival, may drive the proliferation of infected cell clones or, at least, promote their survival [116,120,124,130,131]. In children, selection for integrations in STAT5B and BACH2 was observed both prior to and during long-term ART [127]. However, antigenic stimulus is likely the greatest contributor to the persistence of infected clones. In adults, infected cell clones wax and wane in response to both homeostatic and antigenic stimuli $[118,132]$. T cell receptor $\beta$ chain (TCR $\beta$ ) sequencing paired with integration site analysis reveals that proviral populations in cells responding to chronic viral antigens like CMV, EBV, and influenza are dominated by clones that expand to levels higher than expected by homeostatic proliferation $[133,134]$. These findings are of particular concern in pediatric cohorts from geographical regions where the antigenic burden is high. In Gambia, twothirds of infants have CMV infection by 3 months of age and $85 \%$ by 12 months of age [135]. In Zimbabwe, a study involving 400 children and adolescents living with HIV also found clinically significant levels of CMV DNAemia $(>1000 \mathrm{cp} / \mathrm{mL})$ in $14.7 \%$ of participants [136]. These findings suggest that clonal selection driven by antigenic stimuli may be a major driver of HIV persistence in children from the developing world.

\section{Long-Term Effects of HIV Persistence in Perinatally Infected Individuals}

Although modern ART has revolutionized disease outcomes for children with perinatally acquired HIV, there is growing concern about the consequences of life-long HIV persistence for these individuals. In treated adults, chronic inflammation and immune activation leads to non-AIDS defining comorbidities including cardiovascular, neurocognitive, and metabolic disorders [137]. Due to a longer duration of the persisting infection, adolescents and young adults who acquired HIV in childhood are at an even greater risk for developing illnesses associated with immunosenescence. ART reduces immune activation in children, but levels remain higher than in their uninfected counterparts [138]. Childhood vaccinations and exposure to coinfections may contribute to chronic immune activation [135,136,139-141].

A recent study comparing the frequency of immune cell subsets in young adults with perinatally acquired HIV (aged 18-25 years) and age-matched uninfected controls observed a decrease in mature lymphocytes and CD34+ hematopoietic progenitors in the group with 
HIV, indicating an advanced aging profile [142,143]. Even more striking was the finding that the frequencies of immune components in young adults living with HIV mirrored the immune profiles of uninfected adults over 65 years of age and were associated with persistent viral replication [142]. These findings underscore the challenges of life-long adherence and its potential to accelerate immune aging in the population.

\section{Conclusions}

The immune system in early life provides a unique environment in which perinatal HIV infection is established. Although early treated children with viremia suppressed longterm on ART have smaller and less diverse HIV reservoirs, the proviral landscape during ART is reported to be similar to adults. The ability of early infected cells to persist longterm through clonal expansion poses a major barrier to cure. The effects of life-long HIV persistence and life-long ART are yet to be understood, but growing evidence suggests that these individuals are at an increased risk for developing non-AIDS-related co-morbidities, underscoring the need for an HIV cure (Figures 1 and 2).
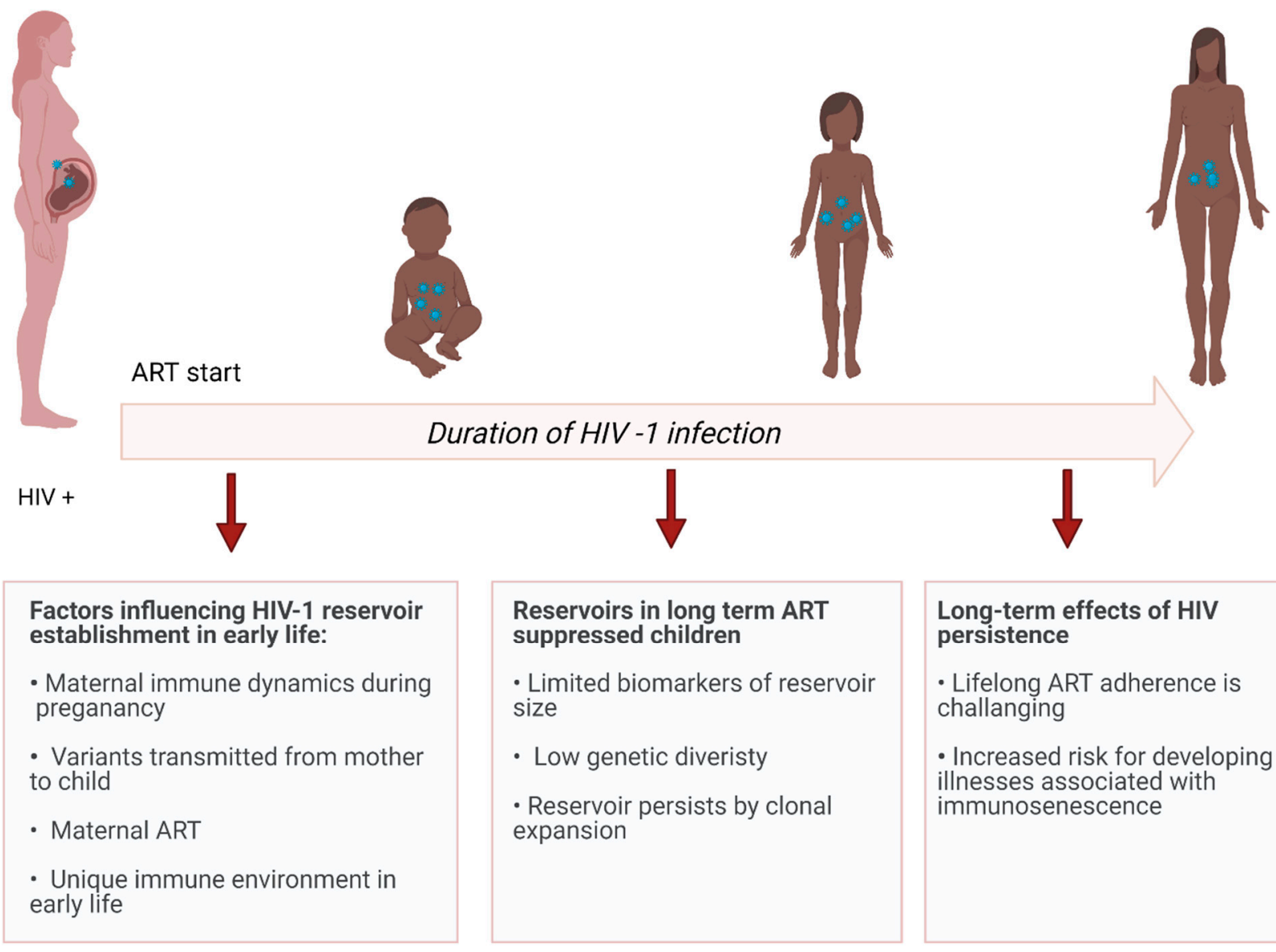

Duration of HIV -1 infection 


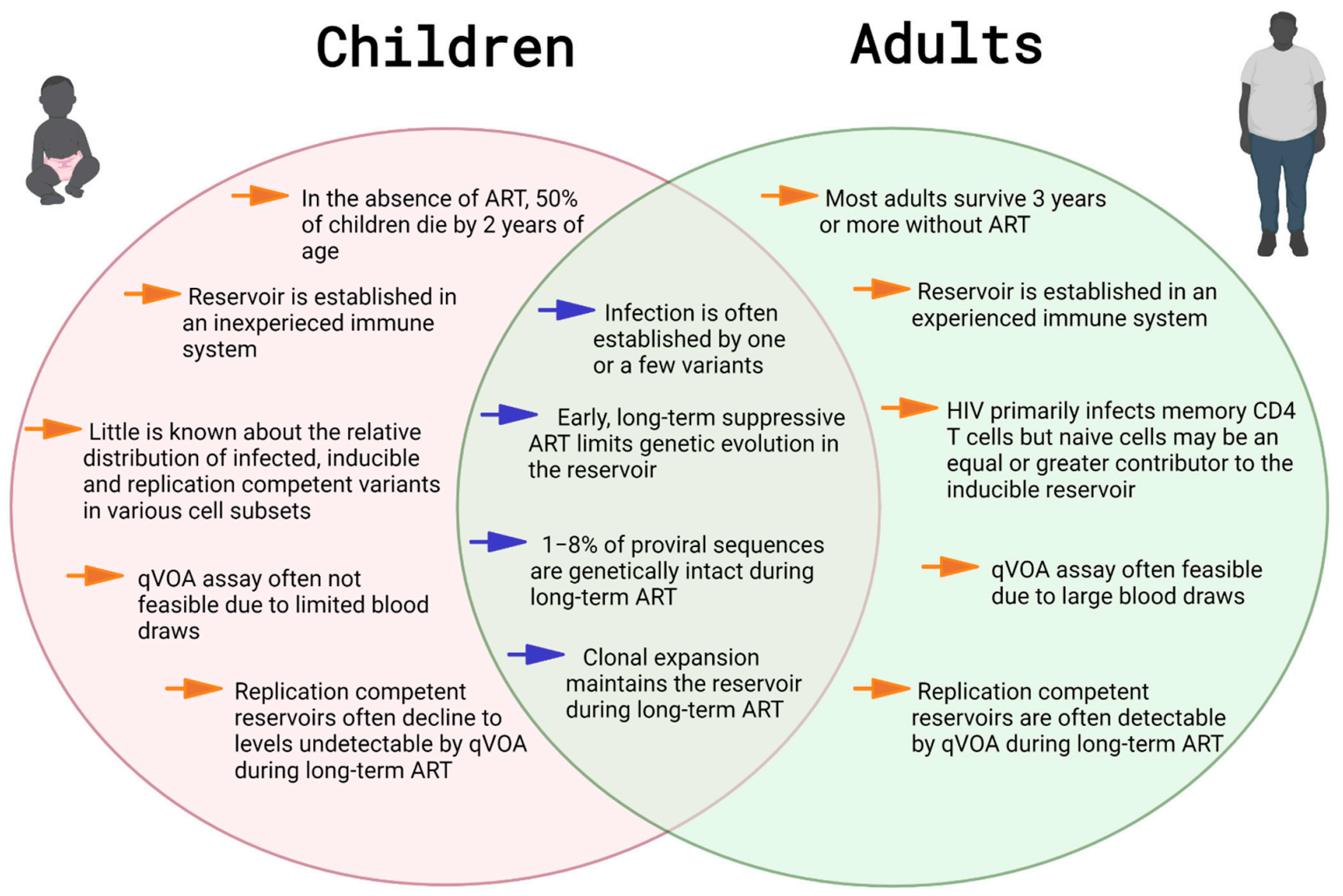

Figure 2. HIV-1 persistence in children vs. adults.

Funding: The authors received grant funding from the National Institute of Allergy and Infectious Diseases (Comprehensive International Program for Research on AIDS (CIPRA) South Africa (U19 AI153217); U.S.-South Africa Program for Collaborative Biomedical Research, National Cancer Institute: U01CA200441; and the Office of AIDS Research (to M.F.K.), Departments of Health of the Western Cape and Gauteng, South Africa, ViiV Healthcare, and National Institute of Mental Health under Award R01MH105134. The content is solely the responsibility of the authors and does not necessarily represent the official views of the NIH.

Conflicts of Interest: The authors declare no conflict of interest.

\section{References}

1. UNAIDS. Global HIV \& AIDS Statistics-2020 Fact Sheet; UNAIDS: Geneva, Switzerland, 2020.

2. Myer, L.; Essajee, S.; Broyles, L.N.; Watts, D.H.; Lesosky, M.; El-Sadr, W.M.; Abrams, E.J. Pregnant and breastfeeding women: A priority population for HIV viral load monitoring. PLoS Med. 2017, 14, e1002375. [CrossRef]

3. Moland, K.M.I.; De Paoli, M.M.; Sellen, D.W.; Van Esterik, P.; Leshabari, S.C.; Blystad, A. Breastfeeding and HIV: Experiences from a decade of prevention of postnatal HIV transmission in sub-Saharan Africa. Int. Breastfeed. J. 2010, 5, 10. [CrossRef]

4. Myburgh, D.; Rabie, H.; Slogrove, A.; Edson, C.; Cotton, M.; Dramowski, A. Horizontal HIV transmission to children of HIV-uninfected mothers: A case series and review of the global literature. Int. J. Infect. Dis. 2020, 98, 315-320. [CrossRef] [PubMed]

5. Scott, G.B.; Brogly, S.B.; Muenz, D.; Stek, A.M.; Read, J.S.; for the International Maternal Pediatric Adolescent AIDS Clinical Trials Group (IMPAACT) P1025 Study Team. Missed Opportunities for Prevention of Mother-to-Child Transmission of Human Immunodeficiency Virus. Obstet. Gynecol. 2017, 129, 621-628. [CrossRef] [PubMed]

6. WHO. Global Health Sector Strategy on HIV 2016-2021 towards Ending AIDS. 2016. Available online: https://apps.who.int/ iris / bitstream/handle/10665/246178/WHO-HIV-2016.05-eng.pdf?sequence=1 (accessed on 2 February 2021).

7. Jewell, B.L.; Mudimu, E.; Stover, J.; Brink, D.T.; Phillips, A.N.; Smith, J.A.; Martin-Hughes, R.; Teng, Y.; Glaubius, R.; Mahiane, S.G.; et al. Potential effects of disruption to HIV programmes in sub-Saharan Africa caused by COVID-19: Results from multiple mathematical models. Lancet HIV 2020, 7, e629-e640. [CrossRef] 
8. Van Elsland, S.L.; Peters, R.P.H.; Grobbelaar, N.; Ketelo, P.; Kok, M.O.; Cotton, M.F.; Van Furth, A.M. Paediatric ART Adherence in South Africa: A comprehensive analysis. AIDS Behav. 2019, 23, 475-488. [CrossRef] [PubMed]

9. Ammon, N.; Mason, S.; Corkery, J. Factors impacting antiretroviral therapy adherence among human immunodeficiency virus-positive adolescents in Sub-Saharan Africa: A systematic review. Public Health 2018, 157, 20-31. [CrossRef]

10. Brown, T.T.; Tassiopoulos, K.; Bosch, R.J.; Shikuma, C.; Mccomsey, G.A. Association Between Systemic Inflammation and Incident Diabetes in HIV-Infected Patients After Initiation of Antiretroviral Therapy. Diabetes Care 2010, 33, 2244-2249. [CrossRef]

11. Nansseu, J.R.; Bigna, J.J.; Kaze, A.D.; Noubiap, J.J. Incidence and risk factors for prediabetes and diabetes mellitus among HIV-infected adults on antiretroviral therapy: A systematic review and meta-analysis. Epidemiology 2018, 29, 431-441. [CrossRef]

12. Van Zoest, R.A.; van den Born, B.-J.H.; Reiss, P. Hypertension in people living with HIV. Curr. Opin. HIV AIDS 2017, 12, 513-522. [CrossRef]

13. Sarfo, F.S.; Singh, A.; Tagge, R.; Mensah, G.; Ovbiagele, B. Duration of antiretroviral therapy among people living with HIV and incidence of hypertension in Ghana. J. Clin. Hypertens. 2020, 22, 2361-2371. [CrossRef]

14. Dimala, C.A.; Blencowe, H.; Choukem, S.P. The association between antiretroviral therapy and selected cardiovascular disease risk factors in sub-Saharan Africa: A systematic review and meta-analysis. PLoS ONE 2018, 13, e0201404. [CrossRef]

15. Sabin, C.A. Do people with HIV infection have a normal life expectancy in the era of combination antiretroviral therapy? BMC Med. 2013, 11, 251. [CrossRef] [PubMed]

16. Brooks, D.G.; Kitchen, S.G.; Kitchen, C.M.R.; Scripture-Adams, D.D.; Zack, J.A. Generation of HIV latency during thymopoiesis. Nat. Med. 2001, 7, 459-464. [CrossRef]

17. Siliciano, R.F.; Greene, W.C. HIV Latency. Cold Spring Harb. Perspect. Med. 2011, 1, a007096. [CrossRef]

18. Chun, T.-W.; Stuyver, L.; Mizell, S.B.; Ehler, L.A.; Mican, J.A.M.; Baseler, M.; Lloyd, A.; Nowak, M.A.; Fauci, A.S. Presence of an inducible HIV-1 latent reservoir during highly active antiretroviral therapy. Proc. Natl. Acad. Sci. USA 1997, 94, 13193-13197. [CrossRef]

19. Newell, M.-L.; Coovadia, H.; Cortina-Borja, M.; Rollins, N.; Gaillard, P.; Dabis, F. Mortality of infected and uninfected infants born to HIV-infected mothers in Africa: A pooled analysis. Lancet 2004, 364, 1236-1243. [CrossRef]

20. Patrikar, S.; Basannar, D.; Bhatti, V.; Kotwal, A.; Gupta, R.; Grewal, R. Rate of decline in CD4 count in HIV patients not on antiretroviral therapy. Med. J. Armed Forces India 2014, 70, 134-138. [CrossRef] [PubMed]

21. Shearer, W.; Quinn, T.C.; LaRussa, P.; Lew, J.F.; Mofenson, L.; Almy, S.; Rich, K.; Handelsman, E.; Diaz, C.; Pagano, M.; et al. Viral load and disease progression in infants infected with human immunodeficiency virus type. N. Engl. J. Med. 1997, 336, 1337-1342. [CrossRef]

22. Lilic, D.; Cant, A.J.; Abinun, M.; Calvert, J.E.; Spickett, G.P. Cytokine production differs in children and adults. Pediatr. Res. 1997, 42, 237-240. [CrossRef] [PubMed]

23. Siegrist, C.-A.; Aspinall, R. B-cell responses to vaccination at the extremes of age. Nat. Rev. Immunol. 2009, 9, 185-194. [CrossRef] [PubMed]

24. Payne, H.; Mkhize, N.N.; Otwombe, K.; Lewis, J.; Panchia, R.; Callard, R.E.; Morris, L.; Babiker, A.; Violari, A.; Cotton, M.F.; et al. Reactivity of routine HIV antibody tests in children who initiated antiretroviral therapy in early infancy as part of the Children with HIV Early Antiretroviral Therapy (CHER) trial: A retrospective analysis. Lancet Infect. Dis. 2015, 15, 803-809. [CrossRef]

25. Shalekoff, S.; Gray, G.E.; Tiemessen, C.T. Age-related changes in expression of CXCR4 and CCR5 on peripheral blood leukocytes from uninfected infants born to human immunodeficiency virus type 1-infected mothers. Clin. Diagn. Lab. Immunol. 2004, 11, 229-234. [CrossRef]

26. Tuttle, D.L.; Coberley, C.R.; Xie, X.; Kou, Z.C.; Sleasman, J.W.; Goodenow, M.M. Effects of human immunodeficiency virus type 1 infection on CCR5 and CXCR4 coreceptor expression on CD4 T lymphocyte subsets in infants and adolescents. AIDS Res. Hum. Retroviruses 2004, 20, 305-313. [CrossRef]

27. Shearer, W.; Rosenblatt, H.M.; Gelman, R.S.; Oyomopito, R.; Plaeger, S.; Stiehm, E.; Wara, D.W.; Douglas, S.D.; Luzuriaga, K.; McFarland, E.J.; et al. Lymphocyte subsets in healthy children from birth through 18 years of age: The pediatric aids clinical trials group P1009 study. J. Allergy Clin. Immunol. 2003, 112, 973-980. [CrossRef]

28. Schatorjé, E.J.; Gemen, E.F.; Driessen, G.J.; Leuvenink, J.; Van Hout, R.W.; De Vries, E. Paediatric reference values for the peripheral T cell compartment. Scand. J. Immunol. 2012, 75, 436-444. [CrossRef]

29. Lynch, H.E.; Goldberg, G.L.; Chidgey, A.; Van den Brink, M.R.; Boyd, R.; Sempowski, G.D. Thymic involution and immune reconstitution. Trends Immunol. 2009, 30, 366-373. [CrossRef] [PubMed]

30. Lee, J.C.; Boechat, M.I.; Belzer, M.; Church, J.A.; De Ville, J.; Nielsen, K.; Weston, S.; Geng, Y.; Dunaway, T.; Kitchen, C.; et al. Thymic volume, T-cell populations, and parameters of thymopoiesis in adolescent and adult survivors of HIV infection acquired in infancy. AIDS 2006, 20, 667-674. [CrossRef] [PubMed]

31. Franco, J.M.; León-Leal, J.A.; Leal, M.; Cano-Rodriguez, A.; Pineda, J.A.; Macías, J.; Rubio, A.; Rey, C.; Sanchez, B.; Lissen, E. $\mathrm{CD}^{+}$and $\mathrm{CD}^{+} \mathrm{T}$ lymphocyte regeneration after anti-retroviral therapy in HIV-1-infected children and adult patients. Clin. Exp. Immunol. 2000, 119, 493-498. [CrossRef] [PubMed]

32. Eriksson, S.; Graf, E.H.; Dahl, V.; Strain, M.C.; Yukl, S.A.; Lysenko, E.S.; Bosch, R.J.; Lai, J.; Chioma, S.; Emad, F.; et al. Comparative analysis of measures of viral reservoirs in HIV-1 eradication studies. PLoS Pathog. 2013, 9, e1003174. [CrossRef]

33. Zerbato, J.M.; Serrao, E.; Lenzi, G.; Kim, B.; Ambrose, Z.; Watkins, S.C.; Engelman, A.N.; Sluis-Cremer, N. Establishment and reversal of HIV-1 latency in naive and central memory CD4+ T cells in vitro. J. Virol. 2016, 90, 8059-8073. [CrossRef] [PubMed] 
34. Zerbato, J.M.; McMahon, D.K.; Sobolewski, M.D.; Mellors, J.W.; Sluis-Cremer, N. Naive CD4 ${ }^{+}$T cells harbor a large inducible reservoir of latent, replication-competent human immunodeficiency virus type. Clin. Infect. Dis. 2019, 69, 1919-1925. [CrossRef] [PubMed]

35. Rullo, E.V.; Cannon, L.; Pinzone, M.R.; Ceccarelli, M.; Nunnari, G.; O'Doherty, U. Genetic evidence that naive T cells can contribute significantly to the human immunodeficiency virus intact reservoir: Time to re-evaluate their role. Clin. Infect. Dis. 2019, 69, 2236-2237. [CrossRef]

36. Chomont, N.; El-Far, M.; Ancuta, P.; Trautmann, L.; Procopio, F.A.; Yassine-Diab, B.; Boucher, G.; Boulassel, M.-R.; Ghattas, G.; Brenchley, J.M.; et al. HIV reservoir size and persistence are driven by T cell survival and homeostatic proliferation. Nat. Med. 2009, 15, 893-900. [CrossRef]

37. Luzuriaga, K.; Tabak, B.; Garber, M.; Chen, Y.H.; Ziemniak, C.; McManus, M.M.; Murray, D.; Strain, M.C.; Richman, D.D.; Chun, T.-W.; et al. HIV type 1 (HIV-1) proviral reservoirs decay continuously under sustained virologic control in HIV-1-infected children who received early treatment. J. Infect. Dis. 2014, 210, 1529-1538. [CrossRef]

38. Veldsman, K.A.; Maritz, J.; Isaacs, S.; Katusiime, M.G.; Van Rensburg, A.J.; Laughton, B.; Mellors, J.W.; Cotton, M.; van Zyl, G. Rapid decline of HIV-1 DNA and RNA in infants starting very early antiretroviral therapy may pose a diagnostic challenge. AIDS (Lond. Engl.) 2018, 32, 629-634. [CrossRef]

39. Bachmann, N.; Von Siebenthal, C.; Vongrad, V.; Turk, T.; Neumann, K.; Beerenwinkel, N.; Bogojeska, J.; Fellay, J.; Roth, V.; Kok, Y.L.; et al. Determinants of HIV-1 reservoir size and long-term dynamics during suppressive ART. Nat. Commun. 2019, 10, 1-11. [CrossRef]

40. Hill, A.L.; Rosenbloom, D.I.S.; Goldstein, E.; Hanhauser, E.; Kuritzkes, D.R.; Siliciano, R.F.; Henrich, T.J. Real-time predictions of reservoir size and rebound time during antiretroviral therapy interruption trials for HIV. PLoS Pathog. 2016, 12, e1005535. [CrossRef] [PubMed]

41. Ioannidis, J.P.A.; Tatsioni, A.; Abrams, E.J.; Bulterys, M.; Coombs, R.W.; Goedert, J.J.; Korber, B.T.; Mayaux, M.J.; Mofenson, L.M.; Moye, J.J.; et al. Maternal viral load and rate of disease progression among vertically HIV-1-infected children: An international meta-analysis. AIDS 2004, 18, 99-108. [CrossRef]

42. Abrams, E.J.; Wiener, J.; Carter, R.; Kuhn, L.; Palumbo, P.; Nesheim, S.; Lee, F.; Vink, P.; Bulterys, M. Maternal health factors and early pediatric antiretroviral therapy influence the rate of perinatal HIV-1 disease progression in children. AIDS 2003, 17, 867-877. [CrossRef] [PubMed]

43. Obimbo, E.M.; Wamalwa, D.; Richardson, B.; Mbori-Ngacha, D.; Overbaugh, J.; Emery, S.; Otieno, P.; Farquhar, C.; Bosire, R.; Payne, B.L.; et al. Pediatric HIV-1 in Kenya: Pattern and correlates of viral load and association with mortality. JAIDS J. Acquir. Immune Defic. Syndr. 2009, 51, 209-215. [CrossRef]

44. Russell, E.S.; Kwiek, J.J.; Keys, J.; Barton, K.; Mwapasa, V.; Montefiori, D.C.; Meshnick, S.R.; Swanstrom, R. The genetic bottleneck in vertical transmission of subtype C HIV-1 is not driven by selection of especially neutralization-resistant virus from the maternal viral population. J. Virol. 2011, 85, 8253-8262. [CrossRef] [PubMed]

45. Derdeyn, C.A.; Decker, J.M.; Bibollet-Ruche, F.; Mokili, J.L.; Muldoon, M.; Denham, S.A.; Heil, M.L.; Kasolo, F.; Musonda, R.; Hahn, B.H.; et al. Envelope-constrained neutralization-sensitive HIV-1 after heterosexual transmission. Science 2004, 303, $2019-2022$. [CrossRef]

46. Kishko, M.; Somasundaran, M.; Brewster, F.; Sullivan, J.L.; Clapham, P.R.; Luzuriaga, K. Genotypic and functional properties of early infant HIV-1 envelopes. Retrovirology 2011, 8, 67. [CrossRef]

47. Kumar, A.; Smith, C.E.P.; Giorgi, E.E.; Eudailey, J.; Martinez, D.R.; Yusim, K.; Douglas, A.O.; Stamper, L.; McGuire, E.; Labranche, C.C.; et al. Infant transmitted/founder HIV-1 viruses from peripartum transmission are neutralization resistant to paired maternal plasma. PLoS Pathog. 2018, 14, e1006944. [CrossRef] [PubMed]

48. Martinez, D.R.; Tu, J.; Kumar, A.; Mangold, J.F.; Mangan, R.J.; Goswami, R.; Giorgi, E.E.; Chen, J.; Mengual, M.; Douglas, A.O.; et al. Maternal broadly neutralizing antibodies can select for neutralization-resistant, infant-transmitted/founder HIV variants. mBio 2020, 11, e00176-20. [CrossRef] [PubMed]

49. Wu, X.; Parast, A.B.; Richardson, B.A.; Nduati, R.; John-Stewart, G.; Mbori-Ngacha, D.; Rainwater, S.M.J.; Overbaugh, J. Neutralization escape variants of human immunodeficiency virus type 1 are transmitted from mother to infant. J. Virol. 2006, 80, 835-844. [CrossRef]

50. Ananworanich, J.; Puthanakit, T.; Suntarattiwong, P.; Chokephaibulkit, K.; Kerr, S.J.; Fromentin, R.; Bakeman, W.; Intasan, J.; Mahanontharit, A.; Sirivichayakul, S.; et al. Reduced markers of HIV persistence and restricted HIV-specific immune responses after early antiretroviral therapy in children. AIDS 2014, 28, 1015-1020. [CrossRef]

51. Lilian, R.R.; Kalk, E.; Technau, K.-G.; Sherman, G.G. Birth diagnosis of HIV infection in infants to reduce infant mortality and monitor for elimination of mother-to-child transmission. Pediatr. Infect. Dis. J. 2013, 32, 1080-1085. [CrossRef]

52. Cotton, M.F.; Violari, A.; Otwombe, K.; Panchia, R.; Dobbels, E.; Rabie, H.; Josipovic, D.; Liberty, A.; Lazarus, E.; Innes, S.; et al Early time-limited antiretroviral therapy versus deferred therapy in South African infants infected with HIV: Results from the children with HIV early antiretroviral (CHER) randomised trial. Lancet 2013, 382, 1555-1563. [CrossRef]

53. Van Zyl, G.; Bedison, M.A.; Van Rensburg, A.J.; Laughton, B.; Cotton, M.F.; Mellors, J.W. Early antiretroviral therapy in South African children reduces HIV-1-infected cells and cell-associated HIV-1 RNA in blood mononuclear cells. J. Infect. Dis. 2015, 212, 39-43. [CrossRef] 
54. De Oliveira, M.F.; Gianella, S.; Letendre, S.; Scheffler, K.; Pond, S.L.K.; Smith, D.M.; Strain, M.; Ellis, R.J. Comparative analysis of cell-associated HIV DNA levels in cerebrospinal fluid and peripheral blood by droplet digital PCR. PLoS ONE 2015, 10, e0139510. [CrossRef]

55. Henrich, T.J.; Gallien, S.; Li, J.Z.; Pereyra, F.; Kuritzkes, D.R. Low-level detection and quantitation of cellular HIV-1 DNA and 2-LTR circles using droplet digital PCR. J. Virol. Methods 2012, 186, 68-72. [CrossRef] [PubMed]

56. Kiselinova, M.; Pasternak, A.; De Spiegelaere, W.; Vogelaers, D.; Berkhout, B.; Vandekerckhove, L. Comparison of droplet digital PCR and seminested real-time PCR for quantification of cell-associated HIV-1 RNA. PLoS ONE 2014, 9, e85999. [CrossRef]

57. Strain, M.C.; Lada, S.M.; Luong, T.; Rought, S.E.; Gianella, S.; Terry, V.H.; Spina, C.A.; Woelk, C.H.; Richman, D.D. Highly precise measurement of HIV DNA by droplet digital PCR. PLOS ONE 2013, 8, e55943. [CrossRef] [PubMed]

58. Archin, N.M.; Vaidya, N.K.; Kuruc, J.D.; Liberty, A.L.; Wiegand, A.; Kearney, M.F.; Cohen, M.S.; Coffin, J.M.; Bosch, R.J.; Gay, C.; et al. Immediate antiviral therapy appears to restrict resting $\mathrm{CD}^{+}$cell HIV-1 infection without accelerating the decay of latent infection. Proc. Natl. Acad. Sci. USA 2012, 109, 9523-9528. [CrossRef]

59. Martínez-Bonet, M.; Puertas, M.C.; Fortuny, C.; Ouchi, D.; Mellado, M.J.; Rojo, P.; Noguera-Julian, A.; Muñoz-Fernández, M.A.; Martinez-Picado, J. Establishment and replenishment of the viral reservoir in perinatally HIV-1-infected children initiating very early antiretroviral therapy. Clin. Infect. Dis. 2015, 61, 1169-1178. [CrossRef]

60. Foster, C.; Pace, M.; Kaye, S.; Hopkins, E.; Jones, M.; Robinson, N.; Mant, C.; Cason, J.; Fidler, S.; Frater, J. Early antiretroviral therapy reduces HIV DNA following perinatal HIV infection. AIDS 2017, 31, 1847-1851. [CrossRef]

61. Van Zyl, G.U.; Katusiime, M.G.; Wiegand, A.; McManus, W.R.; Bale, M.; Halvas, E.K.; Luke, B.; Boltz, V.F.; Spindler, J.; Laughton, B.; et al. No evidence of HIV replication in children on antiretroviral therapy. J. Clin. Investig. 2017, 127, 3827-3834. [CrossRef] [PubMed]

62. Persaud, D.; Patel, K.; Karalius, B.; Rainwater-Lovett, K.; Ziemniak, C.; Ellis, A.; Chen, Y.H.; Richman, U.; Siberry, G.K.; Van Dyke, R.B.; et al. Influence of age at virologic control on peripheral blood human immunodeficiency virus reservoir size and serostatus in perinatally infected adolescents. JAMA Pediatr. 2014, 168, 1138-1146. [CrossRef]

63. Luzuriaga, K. Early combination antiretroviral therapy limits HIV-1 persistence in children. Annu. Rev. Med. 2016, 67, 201-213. [CrossRef] [PubMed]

64. Kuhn, L.; Paximadis, M.; Da Costa Dias, B.; Loubser, S.; Strehlau, R.; Patel, F.; Shiau, S.; Coovadia, A.; Abrams, E.J.; Tiemessen, C.T. Age at antiretroviral therapy initiation and cell-associated HIV-1 DNA levels in HIV-1-infected children. PLoS ONE 2018, 13, e0195514. [CrossRef]

65. Tagarro, A.; Chan, M.; Zangari, P.; Ferns, B.; Foster, C.; De Rossi, A.; Nastouli, E.; Muñoz-Fernández, M.A.; Gibb, D.; Rossi, P.; et al. Early and highly suppressive antiretroviral therapy are main factors associated with low viral reservoir in European perinatally HIV-infected children. JAIDS J. Acquir. Immune Defic. Syndr. 2018, 79, 269-276. [CrossRef] [PubMed]

66. Ajibola, G.; Garcia-Broncano, P.; Maswabi, K.; Bennett, K.; Hughes, M.D.; Moyo, S.; Mohammed, T.; Jean-Philippe, P.; Sakoi, M.; Batlang, O.; et al. Viral reservoir in early-treated HIV-infected children and markers for sustained viral suppression. Clin. Infect. Dis. 2021. [CrossRef] [PubMed]

67. Massanella, M.; Puthanakit, T.; Leyre, L.; Jupimai, T.; Sawangsinth, P.; De Souza, M.; Suntarattiwong, P.; Kosalarksa, P.; Borkird, T.; Kanjanavanit, S.; et al. Continuous prophylactic antiretrovirals/antiretroviral therapy since birth reduces seeding and persistence of the viral reservoir in children vertically infected with human immunodeficiency virus. Clin. Infect. Dis. 2020. [CrossRef]

68. McManus, M.; Mick, E.; Hudson, R.; Mofenson, L.M.; Sullivan, J.L.; Somasundaran, M.; Luzuriaga, K. PACTG 356 investigators early combination antiretroviral therapy limits exposure to HIV-1 replication and cell-associated HIV-1 DNA levels in infants. PLoS ONE 2016, 11, e0154391. [CrossRef]

69. Persaud, D.; Palumbo, P.E.; Ziemniak, C.; Hughes, M.D.; Alvero, C.G.; Luzuriaga, K.; Yogev, R.; Capparelli, E.V.; Chadwick, E.G. Dynamics of the resting $\mathrm{CD}^{+} \mathrm{T}$-cell latent HIV reservoir in infants initiating HAART less than 6 months of age. AIDS 2012, 26, 1483-1490. [CrossRef]

70. Ho, Y.-C.; Shan, L.; Hosmane, N.N.; Wang, J.; Laskey, S.B.; Rosenbloom, D.I.; Lai, J.; Blankson, J.N.; Siliciano, J.D.; Siliciano, R.F. Replication-competent noninduced proviruses in the latent reservoir increase barrier to HIV-1 cure. Cell 2013, 155, 540-551. [CrossRef]

71. Siliciano, J.D.; Siliciano, R.F. Enhanced culture assay for detection and quantitation of latently infected, resting CD4+ T-cells carrying replication-competent virus in HIV-1-infected individuals. Hum. Retrovir. Protoc. 2005, 304, 003-016. [CrossRef]

72. Rosenbloom, D.I.S.; Elliott, O.; Hill, A.L.; Henrich, T.J.; Siliciano, J.M.; Siliciano, R.F. Designing and interpreting limiting dilution assays: General principles and applications to the latent reservoir for human immunodeficiency virus-1. Open Forum Infect. Dis. 2015, 2, ofv123. [CrossRef] [PubMed]

73. Bruner, K.M.; Wang, Z.; Simonetti, F.R.; Bender, A.M.; Kwon, K.J.; Sengupta, S.; Fray, E.J.; Beg, S.A.; Antar, A.; Jenike, K.M.; et al. A quantitative approach for measuring the reservoir of latent HIV-1 proviruses. Nat. Cell Biol. 2019, 566, 120-125. [CrossRef]

74. Chun, T.-W.; Carruth, L.; Finzi, D.; Shen, X.; DiGiuseppe, J.A.; Taylor, H.; Hermankova, M.; Chadwick, K.; Margolick, J.; Quinn, T.C.; et al. Quantification of latent tissue reservoirs and total body viral load in HIV-1 infection. Nat. Cell Biol. 1997, 387, 183-188. [CrossRef] [PubMed]

75. Bruner, K.M.; Murray, A.J.; Pollack, R.A.; Soliman, M.G.; Laskey, S.B.; Capoferri, A.A.; Lai, J.; Strain, M.C.; Lada, S.M.; Hoh, R.; et al. Defective proviruses rapidly accumulate during acute HIV-1 infection. Nat. Med. 2016, 22, 1043-1049. [CrossRef] [PubMed] 
76. Hosmane, N.N.; Kwon, K.J.; Bruner, K.M.; Capoferri, A.A.; Beg, S.; Rosenbloom, D.I.; Keele, B.F.; Ho, Y.-C.; Siliciano, J.D.; Siliciano, R.F. Proliferation of latently infected CD4 ${ }^{+} \mathrm{T}$ cells carrying replication-competent HIV-1: Potential role in latent reservoir dynamics. J. Exp. Med. 2017, 214, 959-972. [CrossRef] [PubMed]

77. Rainwater-Lovett, K.; Ziemniak, C.; Watson, D.; Luzuriaga, K.; Siberry, G.; Petru, A.; Chen, Y.; Uprety, P.; McManus, M.; Ho, Y.-C.; et al. Paucity of intact non-induced provirus with early, long-term antiretroviral therapy of perinatal HIV infection. PLoS ONE 2017, 12, e0170548. [CrossRef]

78. Dhummakupt, A.; Rubens, J.H.; Anderson, T.; Powell, L.; Nonyane, B.A.; Siems, L.V.; Collinson-Streng, A.; Nilles, T.; Jones, R.B.; Tepper, V.; et al. Differences in inducibility of the latent HIV reservoir in perinatal and adult infection. JCI Insight 2020, 5, e134105. [CrossRef]

79. Hill, A.L.; Rosenbloom, D.I.S.; Fu, F.; Nowak, M.A.; Siliciano, R.F. Predicting the outcomes of treatment to eradicate the latent reservoir for HIV. Proc. Natl. Acad. Sci. USA 2014, 111, 13475-13480. [CrossRef]

80. Persaud, D.; Gay, H.; Ziemniak, C.; Chen, Y.H.; Piatak, M.; Chun, T.-W.; Strain, M.; Richman, D.; Luzuriaga, K. Absence of detectable HIV-1 viremia after treatment cessation in an infant. N. Engl. J. Med. 2013, 369, 1828-1835. [CrossRef]

81. Luzuriaga, K.; Gay, H.; Ziemniak, C.; Sanborn, K.B.; Somasundaran, M.; Rainwater-Lovett, K.; Mellors, J.W.; Rosenbloom, D.I.; Persaud, D. Viremic relapse after HIV-1 remission in a perinatally infected child. N. Engl. J. Med. 2015, 372, 786-788. [CrossRef]

82. Frange, P.; Faye, A.; Avettand-Fenoël, V.; Bellaton, E.; Descamps, D.; Angin, M.; David, A.; Caillat-Zucman, S.; Peytavin, G.; Dollfus, C.; et al. HIV-1 virological remission lasting more than 12 years after interruption of early antiretroviral therapy in a perinatally infected teenager enrolled in the French ANRS EPF-CO10 paediatric cohort: A case report. Lancet HIV 2016, 3, e49-e54. [CrossRef]

83. Violari, A.; Cotton, M.F.; Kuhn, L.; Schramm, D.B.; Paximadis, M.; Loubser, S.; Shalekoff, S.; Da Costa Dias, B.; Otwombe, K.; Liberty, A.; et al. A child with perinatal HIV infection and long-term sustained virological control following antiretroviral treatment cessation. Nat. Commun. 2019, 10, 412. [CrossRef] [PubMed]

84. Colby, D.J.; Trautmann, L.; Pinyakorn, S.; Leyre, L.; Pagliuzza, A.; Kroon, E.; Rolland, M.; Takata, H.; Buranapraditkun, S.; Intasan, J.; et al. Rapid HIV RNA rebound after antiretroviral treatment interruption in persons durably suppressed in Fiebig I acute HIV infection. Nat. Med. 2018, 24, 923-926. [CrossRef] [PubMed]

85. Sáez-Cirión, A.; Bacchus, C.; Hocqueloux, L.; Avettand-Fenoel, V.; Girault, I.; Lecuroux, C.; Potard, V.; Versmisse, P.; Melard, A.; Prazuck, T.; et al. Post-treatment HIV-1 controllers with a long-term virological remission after the interruption of early initiated antiretroviral therapy ANRS VISCONTI study. PLoS Pathog. 2013, 9, e1003211. [CrossRef]

86. Trautmann, L. How to generate good killers by initiating ART (not too) early? In Proceedings of the Conference on Retroviruses and Oppourtunisitc Infections, Virtual, 6-10 March 2021; Available online: https:/ /www.croiconference.org/abstract/how-togenerate-good-killers-by-initiating-art-not-too-early/ (accessed on 12 March 2021).

87. Wagner, T.A.; McKernan, J.L.; Tobin, N.H.; Tapia, K.A.; Mullins, J.I.; Frenkel, L.M. An increasing proportion of monotypic HIV-1 DNA sequences during antiretroviral treatment suggests proliferation of HIV-infected cells. J. Virol. 2012, 87, 1770-1778. [CrossRef] [PubMed]

88. Castro-Nallar, E.; Pérez-Losada, M.; Burton, G.F.; Crandall, K.A. The evolution of HIV: Inferences using phylogenetics. Mol. Phylogenetics Evol. 2012, 62, 777-792. [CrossRef]

89. Hammer, S.M.; Ribaudo, H.; Bassett, R.; Mellors, J.W.; Demeter, L.M.; Coombs, R.W.; Currier, J.; Morse, G.D.; Gerber, J.G.; Martinez, A.I.; et al. A randomized, placebo-controlled trial of abacavir intensification in HIV-1-infected adults with virologic suppression on a protease inhibitor-containing regimen. HIV Clin. Trials 2010, 11, 312-324. [CrossRef]

90. Persaud, D.; Ray, S.C.; Kajdas, J.; Ahonkhai, A.; Siberry, G.K.; Ferguson, K.; Ziemniak, C.; Quinn, T.C.; Casazza, J.P.; Zeichner, S.; et al. Slow human immunodeficiency virus type 1 evolution in viral reservoirs in infants treated with effective antiretroviral therapy. AIDS Res. Hum. Retrovir. 2007, 23, 381-390. [CrossRef] [PubMed]

91. Van Zyl, G.; Bale, M.J.; Kearney, M.F. HIV evolution and diversity in ART-treated patients. Retrovirology 2018, 15, 1-12. [CrossRef]

92. Sanchez-Merino, V.; Nie, S.; Luzuriaga, K. HIV-1-specific CD8 ${ }^{+} \mathrm{T}$ cell responses and viral evolution in women and infants. J. Immunol. 2005, 175, 6976-6986. [CrossRef]

93. Kearney, M.F.; Wiegand, A.; Shao, W.; Coffin, J.M.; Mellors, J.W.; Lederman, M.; Gandhi, R.T.; Keele, B.F.; Li, J.Z. Origin of rebound plasma HIV includes cells with identical proviruses that are transcriptionally active before stopping of antiretroviral therapy. J. Virol. 2016, 90, 1369-1376. [CrossRef]

94. Kearney, M.F.; Spindler, J.; Shao, W.; Yu, S.; Anderson, E.M.; O'Shea, A.; Rehm, C.; Poethke, C.; Kovacs, N.; Mellors, J.W.; et al. Lack of detectable HIV-1 molecular evolution during suppressive antiretroviral therapy. PLoS Pathog. 2014, 10, e1004010. [CrossRef]

95. Veldsman, K.A.; Van Rensburg, A.J.; Isaacs, S.; Naidoo, S.; Laughton, B.; Lombard, C.; Cotton, M.F.; Mellors, J.W.; Van Zyl, G.U. HIV-1DNA decay is faster in children who initiate ART shortly after birth than later. J. Int. AIDS Soc. 2019, 22, e25368. [CrossRef] [PubMed]

96. Uprety, P.; Chadwick, E.G.; Rainwater-Lovett, K.; Ziemniak, C.; Luzuriaga, K.; Capparelli, E.V.; Yenokyan, G.; Persaud, D. Cell-associated HIV-1 DNA and RNA decay dynamics during early combination antiretroviral therapy in HIV-1-infected infants. Clin. Infect. Dis. 2015, 61, 1862-1870. [CrossRef]

97. Ananworanich, J.; Chomont, N.; Eller, L.A.; Kroon, E.; Tovanabutra, S.; Bose, M.; Nau, M.; Fletcher, J.L.; Tipsuk, S.; Vandergeeten, C.; et al. HIV DNA set point is rapidly established in acute HIV infection and dramatically reduced by early ART. EBioMedicine 2016, 11, 68-72. [CrossRef] [PubMed] 
98. Besson, G.J.; Lalama, C.M.; Bosch, R.J.; Gandhi, R.T.; Bedison, M.A.; Aga, E.; Riddler, S.A.; McMahon, D.K.; Hong, F.; Mellors, J.W. HIV-1 DNA decay dynamics in blood during more than a decade of suppressive antiretroviral therapy. Clin. Infect. Dis. 2014, 59, 1312-1321. [CrossRef] [PubMed]

99. Buzon, M.J.; Martin-Gayo, E.; Pereyra, F.; Ouyang, Z.; Sun, H.; Li, J.Z.; Piovoso, M.; Shaw, A.; Dalmau, J.; Zangger, N.; et al. Long-term antiretroviral treatment initiated at primary HIV-1 infection affects the size, composition, and decay kinetics of the reservoir of HIV-1-infected CD4 T cells. J. Virol. 2014, 88, 10056-10065. [CrossRef] [PubMed]

100. Fischer, M.; Joos, B.; Niederöst, B.; Kaiser, P.; Hafner, R.; Von Wyl, V.; Ackermann, M.; Weber, R.; Günthard, H.F. Biphasic decay kinetics suggest progressive slowing in turnover of latently HIV-1 infected cells during antiretroviral therapy. Retrovirology 2008, 5, 107. [CrossRef] [PubMed]

101. Crooks, A.M.; Bateson, R.; Cope, A.B.; Dahl, N.P.; Griggs, M.K.; Kuruc, J.D.; Gay, C.; Eron, J.J.; Margolis, D.M.; Bosch, R.J.; et al. Precise quantitation of the latent HIV-1 reservoir: Implications for eradication strategies. J. Infect. Dis. 2015, 212, 1361-1365. [CrossRef]

102. Siliciano, J.D.; Kajdas, J.; Finzi, D.; Quinn, T.C.; Chadwick, K.; Margolick, J.B.; Kovacs, C.; Gange, S.; Siliciano, R.F. Long-term follow-up studies confirm the stability of the latent reservoir for HIV-1 in resting CD4 ${ }^{+}$T cells. Nat. Med. 2003, 9, 727-728. [CrossRef]

103. Antar, A.; Jenike, K.M.; Jang, S.; Rigau, D.N.; Reeves, D.B.; Hoh, R.; Krone, M.R.; Keruly, J.C.; Moore, R.D.; Schiffer, J.T.; et al. Longitudinal study reveals HIV-1-infected CD4 ${ }^{+} \mathrm{T}$ cell dynamics during long-term antiretroviral therapy. J. Clin. Investig. 2020, 130, 3543-3559. [CrossRef]

104. Peluso, M.J.; Bacchetti, P.; Ritter, K.D.; Beg, S.; Lai, J.; Martin, J.N.; Hunt, P.W.; Henrich, T.J.; Siliciano, J.D.; Siliciano, R.F.; et al. Differential decay of intact and defective proviral DNA in HIV-1-infected individuals on suppressive antiretroviral therapy. JCI Insight 2020, 5. [CrossRef]

105. Garcia-Broncano, P.; Maddali, S.; Einkauf, K.B.; Jiang, C.; Gao, C.; Chevalier, J.; Chowdhury, F.Z.; Maswabi, K.; Ajibola, G.; Moyo, S.; et al. Early antiretroviral therapy in neonates with HIV-1 infection restricts viral reservoir size and induces a distinct innate immune profile. Sci. Transl. Med. 2019, 11, eaax7350. [CrossRef] [PubMed]

106. Hiener, B.; Horsburgh, B.A.; Eden, J.-S.; Barton, K.; Schlub, T.E.; Lee, E.; von Stockenstrom, S.; Odevall, L.; Milush, J.M.; Liegler, T.; et al. Identification of genetically intact HIV-1 proviruses in specific CD4 ${ }^{+} \mathrm{T}$ cells from effectively treated participants. Cell Rep. 2017, 21, 813-822. [CrossRef] [PubMed]

107. Bebenek, K.; Abbotts, J.; Roberts, J.D.; Wilson, S.; Kunkel, T.A. Specificity and mechanism of error-prone replication by human immunodeficiency virus-1 reverse transcriptase. J. Biol. Chem. 1989, 264, 16948-16956. [CrossRef]

108. Kieffer, T.L.; Kwon, P.; Nettles, R.E.; Han, Y.; Ray, S.C.; Siliciano, R.F.G. A hypermutation in protease and reverse transcriptase regions of human immunodeficiency virus type 1 residing in resting CD4 ${ }^{+}$T cells in vivo. J. Virol. 2005, 79, 1975-1980. [CrossRef]

109. Sanchez, G.; Xu, X.; Chermann, J.C.; Hirsch, I. Accumulation of defective viral genomes in peripheral blood mononuclear cells of human immunodeficiency virus type 1-infected individuals. J. Virol. 1997, 71, 2233-2240. [CrossRef]

110. Simonetti, F.R.; White, J.A.; Tumiotto, C.; Ritter, K.D.; Cai, M.; Gandhi, R.T.; Deeks, S.G.; Howell, B.J.; Montaner, L.J.; Blankson, J.N.; et al. Intact proviral DNA assay analysis of large cohorts of people with HIV provides a benchmark for the frequency and composition of persistent proviral DNA. Proc. Natl. Acad. Sci. USA 2020, 117, 18692-18700. [CrossRef]

111. Katusiime, M.G.; Halvas, E.K.; Wright, I.; Joseph, K.; Bale, M.J.; Kirby-McCullough, B.; Engelbrecht, S.; Shao, W.; Hu, W.-S.; Cotton, M.F.; et al. Intact HIV proviruses persist in children seven to nine years after initiation of antiretroviral therapy in the first year of life. J. Virol. 2020, 94, e01519-19. [CrossRef]

112. Anderson, J.A.; Archin, N.M.; Ince, W.; Parker, D.; Wiegand, A.; Coffin, J.M.; Kuruc, J.; Eron, J.; Swanstrom, R.; Margolis, D.M. Clonal sequences recovered from plasma from patients with residual HIV-1 viremia and on intensified antiretroviral therapy are identical to replicating viral RNAs recovered from circulating resting CD4 ${ }^{+}$T cells. J. Virol. 2011, 85, 5220-5223. [CrossRef]

113. Bailey, J.R.; Sedaghat, A.R.; Kieffer, T.; Brennan, T.; Lee, P.K.; Wind-Rotolo, M.; Haggerty, C.M.; Kamireddi, A.R.; Liu, Y.; Lee, J.; et al. Residual human immunodeficiency virus type 1 viremia in some patients on antiretroviral therapy is dominated by a small number of invariant clones rarely found in circulating CD4 ${ }^{+} \mathrm{T}$ cells. J. Virol. 2006, 80, 6441-6457. [CrossRef]

114. Evering, T.H.; Mehandru, S.; Racz, P.; Tenner-Racz, K.; Poles, M.; Figueroa, A.; Mohri, H.; Markowitz, M. Absence of HIV-1 evolution in the gut-associated lymphoid tissue from patients on combination antiviral therapy initiated during primary infection. PLoS Pathog. 2012, 8, e1002506. [CrossRef] [PubMed]

115. Bull, M.; Learn, G.; Genowati, I.; McKernan, J.; Hitti, J.; Lockhart, D.; Tapia, K.; Holte, S.; Dragavon, J.; Coombs, R.; et al Compartmentalization of HIV-1 within the female genital tract is due to monotypic and low-diversity variants not distinct viral populations. PLoS ONE 2009, 4, e7122. [CrossRef] [PubMed]

116. Wagner, T.A.; McLaughlin, S.; Garg, K.; Cheung, C.Y.K.; Larsen, B.B.; Styrchak, S.; Huang, H.C.; Edlefsen, P.T.; Mullins, J.I.; Frenkel, L.M. Proliferation of cells with HIV integrated into cancer genes contributes to persistent infection. Science 2014, 345, 570-573. [CrossRef]

117. Patro, S.C.; Brandt, L.D.; Bale, M.; Halvas, E.K.; Joseph, K.W.; Shao, W.; Wu, X.; Guo, S.; Murrell, B.; Wiegand, A.; et al. Combined HIV-1 sequence and integration site analysis informs viral dynamics and allows reconstruction of replicating viral ancestors. Proc. Natl. Acad. Sci. USA 2019, 116, 25891-25899. [CrossRef] [PubMed]

118. Simonetti, F.R.; Sobolewski, M.D.; Fyne, E.; Shao, W.; Spindler, J.; Hattori, J.; Anderson, E.M.; Watters, S.A.; Hill, S.; Wu, X.; et al. Clonally expanded CD4 ${ }^{+}$T cells can produce infectious HIV-1 in vivo. Proc. Natl. Acad. Sci. USA 2016, 113, 1883-1888. [CrossRef] 
119. Einkauf, K.B.; Lee, G.Q.; Gao, C.; Sharaf, R.; Sun, X.; Hua, S.; Chen, S.M.; Jiang, C.; Lian, X.; Chowdhury, F.Z.; et al. Intact HIV-1 proviruses accumulate at distinct chromosomal positions during prolonged antiretroviral therapy. J. Clin. Investig. 2019, 129, 988-998. [CrossRef]

120. Maldarelli, F.; Wu, X.; Su, L.; Simonetti, F.R.; Shao, W.; Hill, S.; Spindler, J.; Ferris, A.L.; Mellors, J.W.; Kearney, M.F.; et al. Specific HIV integration sites are linked to clonal expansion and persistence of infected cells. Research Support, N.I.H.; Extramural Research Support, Non-U.S. Gov't. Science 2014, 345, 179-183. [CrossRef]

121. Bui, J.K.; Sobolewski, M.D.; Keele, B.F.; Spindler, J.; Musick, A.; Wiegand, A.; Luke, B.T.; Shao, W.; Hughes, S.H.; Coffin, J.M.; et al. Proviruses with identical sequences comprise a large fraction of the replication-competent HIV reservoir. PLoS Pathog. 2017, 13, e1006283. [CrossRef]

122. Halvas, E.K.; Joseph, K.W.; Brandt, L.D.; Guo, S.; Sobolewski, M.D.; Jacobs, J.L.; Tumiotto, C.; Bui, J.K.; Cyktor, J.C.; Keele, B.F.; et al. HIV-1 viremia not suppressible by antiretroviral therapy can originate from large $\mathrm{T}$ cell clones producing infectious virus. J. Clin. Investig. 2020, 130, 5847-5857. [CrossRef]

123. Lorenzi, J.C.C.; Cohen, Y.Z.; Cohn, L.B.; Kreider, E.; Barton, J.P.; Learn, G.H.; Oliveira, T.; Lavine, C.L.; Horwitz, J.A.; Settler, A.; et al. Paired quantitative and qualitative assessment of the replication-competent HIV-1 reservoir and comparison with integrated proviral DNA. Proc. Natl. Acad. Sci. USA 2016, 113, E7908-E7916. [CrossRef]

124. Cohn, L.B.; Silva, I.T.; Oliveira, T.Y.; Rosales, R.A.; Parrish, E.H.; Learn, G.H.; Hahn, B.H.; Czartoski, J.L.; McElrath, M.J.; Lehmann, C.; et al. HIV-1 integration landscape during latent and active infection. Cell 2015, 160, 420-432. [CrossRef] [PubMed]

125. Kim, M.; Siliciano, R.F. Reservoir expansion by T-cell proliferation may be another barrier to curing HIV infection. Proc. Natl. Acad. Sci. USA 2016, 113, 1692-1694. [CrossRef]

126. Pinzone, M.R.; VanBelzen, D.J.; Weissman, S.; Bertuccio, M.P.; Cannon, L.; Hwang, W.-T.; Sherman, B.; O’Doherty, U. Proviral sequencing suggests the majority of the HIV reservoir is expressed over time but significant decay is obscured by clonal expansion. bioRxiv 2018, 348409. [CrossRef]

127. Bale, M.J.; Katusiime, M.G.; Wells, D.; Wu, X.; Spindler, J.; Halvas, E.K.; Cyktor, J.C.; Wiegand, A.; Shao, W.; Cotton, M.F.; et al. Early emergence and long-term persistence of HIV-infected T-cell clones in children. mBio 2021, 12, e00568-21. [CrossRef] [PubMed]

128. Coffin, J.M.; Wells, D.W.; Zerbato, J.M.; Kuruc, J.D.; Guo, S.; Luke, B.T.; Eron, J.J.; Bale, M.; Spindler, J.; Simonetti, F.R.; et al. Clones of infected cells arise early in HIV-infected individuals. JCI Insight 2019, 4, e128432. [CrossRef]

129. Boshier, F.A.T.; Reeves, D.B.; Duke, E.R.; Swan, D.A.; Prlic, M.; Cardozo-Ojeda, E.F.; Schiffer, J.T. Blind uneven proliferation of $\mathrm{CD}^{+} \mathrm{T}$ cells during primary infection generates the majority of the HIV reservoir. medRxiv 2020. [CrossRef]

130. Cesana, D.; De Sio, F.R.S.; Rudilosso, L.; Gallina, P.; Calabria, A.; Beretta, S.; Merelli, I.; Bruzzesi, E.; Passerini, L.; Nozza, S.; et al. HIV-1-mediated insertional activation of STAT5B and BACH2 trigger viral reservoir in T regulatory cells. Nat. Commun. 2017, 8, 1-11. [CrossRef]

131. Ikeda, T.; Shibata, J.; Yoshimura, K.; Koito, A.; Matsushita, S. Recurrent HIV-1 integration at the BACH2 locus in resting CD4 ${ }^{+} \mathrm{T}$ cell populations during effective highly active antiretroviral therapy. J. Infect. Dis. 2007, 195, 716-725. [CrossRef]

132. Wang, Z.; Gurule, E.E.; Brennan, T.P.; Gerold, J.M.; Kwon, K.J.; Hosmane, N.N.; Kumar, M.R.; Beg, S.A.; Capoferri, A.A.; Ray, S.C.; et al. Expanded cellular clones carrying replication-competent HIV-1 persist, wax, and wane. Proc. Natl. Acad. Sci. USA 2018, 115, E2575-E2584. [CrossRef]

133. Simonetti, F.R.; Zhang, H.; Soroosh, G.P.; Duan, J.; Rhodehouse, K.; Hill, A.L.; Beg, S.A.; McCormick, K.; Raymond, H.E.; Nobles, C.L.; et al. Antigen-driven clonal selection shapes the persistence of HIV-1-infected CD4 ${ }^{+} \mathrm{T}$ cells in vivo. J. Clin. Investig. 2021, 131. [CrossRef]

134. Mendoza, P.; Jackson, J.R.; Oliveira, T.Y.; Gaebler, C.; Ramos, V.; Caskey, M.; Jankovic, M.; Nussenzweig, M.C.; Cohn, L.B. Antigen-responsive $\mathrm{CD}^{+} \mathrm{T}$ cell clones contribute to the HIV-1 latent reservoir. J. Exp. Med. 2020, 217. [CrossRef]

135. Miles, D.J.C.; van der Sande, M.; Jeffries, D.; Kaye, S.; Ismaili, J.; Ojuola, O.; Sanneh, M.; Touray, E.S.; Waight, P.; Rowland-Jones, S.; et al. Cytomegalovirus infection in gambian infants leads to profound CD8 T-cell differentiation. J. Virol. 2007, 81, 5766-5776. [CrossRef]

136. Yindom, L.-M.; Simms, V.; Majonga, E.D.; McHugh, G.; Dauya, E.; Bandason, T.; Vincon, H.; Rylance, J.; Munyati, S.; Ferrand, R.A.; et al. Unexpectedly high prevalence of cytomegalovirus DNA emia in older children and adolescents with perinatally acquired human immunodeficiency virus infection. Clin. Infect. Dis. 2019, 69, 580-587. [CrossRef]

137. Horvat, T.; Adel, N.G.; Dang, T.-O.; Momtaz, P.; Postow, M.A.; Callahan, M.K.; Carvajal, R.D.; Dickson, M.A.; D’Angelo, S.P.; Woo, K.M.; et al. Immune-related adverse events, need for systemic immunosuppression, and effects on survival and time to treatment failure in patients with melanoma treated with ipilimumab at memorial sloan kettering cancer center. J. Clin. Oncol. 2015, 33, 3193-3198. [CrossRef]

138. Cotugno, N.; Douagi, I.; Rossi, P.; Palma, P. Suboptimal immune reconstitution in vertically HIV infected children: A view on how HIV replication and timing of HAART initiation can impact on T and B-cell compartment. Clin. Dev. Immunol. 2012, $2012,805151$. [CrossRef]

139. Bekker, V.; Westerlaken, G.H.A.; Scherpbier, H.J.; Alders, S.; Zaaijer, H.L.; Van Baarle, D.; Kuijpers, T. Varicella vaccination in HIV-1-infected children after immune reconstitution. AIDS 2006, 20, 2321-2329. [CrossRef] [PubMed] 
140. Gasper, M.A.; Hesseling, A.C.; Mohar, I.; Myer, L.; Azenkot, T.; Passmore, J.-A.S.; Hanekom, W.; Cotton, M.F.; Crispe, I.N.; Sodora, N.L.; et al. BCG vaccination induces HIV target cell activation in HIV-exposed infants in a randomized trial. JCI Insight 2017, 2, e91963. [CrossRef] [PubMed]

141. Hesseling, A.C.; Caldwell, J.; Cotton, M.F.; Eley, B.S.; Jaspan, H.B.; Jennings, K.; Marais, B.J.; Nuttall, J.; Rabie, H.; Roux, P.; et al. BCG vaccination in South African HIV-exposed infants-Risks and benefits. S. Afr. Med. J. 2009, 99, 88-91. [PubMed]

142. Fastenackels, S.; Sauce, D.; Vigouroux, C.; Avettand-Fènoël, V.; Bastard, J.-P.; Fellahi, S.; Nailler, L.; Arezes, E.; Rouzioux, C.; Warszawski, J.; et al. HIV-mediated immune aging in young adults infected perinatally or during childhood. AIDS 2019, 33, 1705-1710. [CrossRef] [PubMed]

143. Williams, D.W.; Elahi, S. Profound immune consequences for young adults infected with HIV perinatally or during childhood: A cautionary tale regarding adherence to antiretroviral therapy. AIDS 2019, 33, 2251-2252. [CrossRef] 